\title{
IS CONSANGUINEOUS MARRIAGE RESPONSIBLE FOR CONGENITAL CARDIAC AND EXTRA-CARDIAC ANOMALIES?
}

\author{
Nutan Nalini Bage1, Sudha Rao ${ }^{2}$ \\ ${ }^{1}$ Associate Professor, Department of Anatomy, PIMS, Pondicherry. \\ ${ }^{2}$ Ex-Director, Professor and HOD, Department of Anatomy, JIPMER, Pondicherry.
}

\begin{tabular}{l}
\hline ABSTRACT \\
\hline BACKGROUND \\
This article is about the stillbirth in which we found significant numbers of cardiac as well as extracardiac defects, in combination \\
or separately. In this article, we would like to emphasize the anomalies found in consanguineous marriages.
\end{tabular}

AIM

To correlate the prevalence of cardiac as well as extracardiac anomalies in consanguineous marriages. Especially, here we would like to focus on the cardiac lesions.

\section{MATERIAL AND METHOD}

The study was carried out in 44 still birth foetuses with detailed account of parentage. Significant number of cases with cardiac and extracardiac anomalies was found.

\section{RESULTS}

Out of total 44 stillbirth foetuses, 13 stillbirths were from consanguineous marriages in which 09 had cardiac anomalies. Interrupted aortic arch-02, Abnormal origin of right Subclavian artery- 01, Tetralogy of Fallot- 01, VSD- 04, ASD-01. The extra cardiac findings included Gastroschisis-01, Anencephaly with spina bifida-01, cleft lip/palate-01, polydactyly and syndactyly of ring and little finger-01, limb deformity-01, hydrocephalus-01, craniothoracopagus- 01 .

\section{CONCLUSION}

Considering the high incidence of cardiac and extracardiac anomalies in consanguineous parentage we must try to create an awareness to avoid the practice of consanguineous marriages in society.

\section{KEYWORDS}

Still Birth, Cardiac Anomalies, Extracardiac Anomalies, Consanguineous Marriage (CM).

HOW TO CITE THIS ARTICLE: Bage NN, Rao S. Is consanguineous marriage responsible for congenital cardiac and extra-cardiac anomalies? J. Evolution Med. Dent. Sci. 2016;5(19):930-932, DOI: 10.14260/jemds/2016/216

\section{INTRODUCTION}

It is very important to discuss the consanguineous marriage in our society as plenty of congenital anomalies are associated with it and although we have the approval in some societies, the infant has to face many a condition, if living, which is not curable. Healthcare providers and genetics specialists have usually judged as being negative, the overall impact when assessed in terms of increased genetic risks to the offspring as opposed to the potential social and economic benefits.

More than $20 \%$ of the world population favours consanguineous marriages because of its social benefits. It certainly is supportive to the women in paternal descent of families in the developing countries. In the Middle East, it has been in vogue for thousands of years and approximately $6.5 \%$ of couples actually make such a marriage world-wide. Despite the religious and legal sanctions imposed by certain societies, consanguineous marriages still prevail in certain social groups, which have varied attitudes toward them with all their associated prejudices and problems.

Financial or Other, Competing Interest: None.

Submission 21-01-2016, Peer Review 15-02-2016,

Acceptance 22-02-2016, Published 04-03-2016.

Corresponding Author:

Dr. Nutan N. Bage,

Plot No.39, 40. Messiah Street,

Raja Annamalainagar, Gorimedu,

Pondicherry-605006.

E-mail: nutanbage@yahoo.com

DOI: $10.14260 /$ jemds $/ 2016 / 216$
The prevalence of such marriages is dictated to a large extent, by culture, religion, tradition and civil laws. ${ }^{1}$

The aetiology of congenital malformation (CM) is genetic (30-40\%) and environmental (5 to $10 \%$ ). Among the genetic aetiology, chromosomal abnormality constitutes $6 \%$, single gene disorders $25 \%$ and multifactorial $20-30 \%$; however, for nearly $50 \%$ of $\mathrm{CM}$, the cause is yet to be known. ${ }^{2}$ These are the few factors which come in mind in the absence of consanguinity. Although medical science has progressed by leaps and bounds, but still lot of thing remains unanswered.

Consanguineous marriages have been described as an important factor contributing to increased congenital malformations. $^{3}$ It can be characterized by the degree of relatedness between the spouses: first cousins, double first cousins, half first cousins, first cousins once removed, second cousins, second cousins once removed and third cousins.

Because of high consanguinity rates within the Muslim population, the incidence of $\mathrm{CM}$ in Islamic countries is between 10 to $45 \%{ }^{4}$

\section{MATERIAL AND METHOD}

A total number of 44 stillbirth foetuses of varying gestational age of both sexes of known and unknown causes were procured from the Department of Obstetrics and Gynaecology, JIPMER. It was quite a humbling experience to ask the parents for permission to take away the foetus for examination. The study was conducted in the Department of Anatomy, JIPMER, Pondicherry. 
Detailed history of mother was taken, especially in terms of consanguinity, history of previous pregnancies, miscarriages, socio-economic status and exposure to drugs/radiation, possible cause of foetal death and mode of termination.

Consent for autopsy and embalming was obtained from the parents, the foetuses were subjected to detailed external physical examination and the anomalies were noted. A midline incision was given below the chin to pubic symphysis to open the neck, thorax and peritoneal cavity. The detailed anomalies both cardiac and extracardiac was recorded and analysed.

\section{RESULTS}

As per our study a total number of 44 stillbirth foetuses were embalmed and dissected. All the foetuses had some anomalies, cardiac and/or extracardiac; 13 cases were from the consanguineous parents in which we found 09 foetuses with cardiac anomalies and rest with associated extracardiac anomalies. Total number of 31 , among non-consanguineous parents had 11 cardiac anomalies and 20 with extracardiac or no anomaly. Among the consanguineous group, we found the following; Interrupted aortic arch-02, Abnormal origin of right subclavian artery-01, Tetralogy of Fallot-01 and VSD-04, ASD01 . Along with it the extracardiac findings were Anencephaly01 with spina bifida- 01 , cleft lip/palate-01, polydactyly and syndactyly of ring and little finger, Gastroschisis- 01 with limb deformity-01, Hydrocephalus-01, craniothoracopagus-01.

\begin{tabular}{|c|c|c|c|}
\hline & $\begin{array}{c}\text { Cardiac } \\
\text { Anomalies } \\
\text { Present }\end{array}$ & $\begin{array}{c}\text { Cardiac } \\
\text { Anomalies } \\
\text { Absent }\end{array}$ & Total \\
\hline Consanguineous & 09 & 04 & 13 \\
\hline $\begin{array}{c}\text { Non- } \\
\text { consanguineous }\end{array}$ & 11 & 20 & 31 \\
\hline $\begin{array}{c}\text { Marginal } \\
\text { Column Total }\end{array}$ & 20 & 24 & $\begin{array}{c}44 \text { (Grand } \\
\text { Total) }\end{array}$ \\
\hline \multicolumn{4}{|c}{ Table 1 } \\
\hline
\end{tabular}

The Chi square $=4.2071$. The $p$-value is $0.040255, p<0.05$, significant.

As per the table in consanguineous marriage foetus, we found 09 foetuses with cardiac anomalies and other extracardiac anomalies and 04 without cardiac anomalies. In non-consanguineous marriage, there were 11 foetus with the cardiac anomalies and 20 without cardiac anomalies. Since the $\mathrm{p}$-value is also $<.005$, it is quite significant. The number of cases is less in this series, if it had been more the significance would have been more marked.

\begin{tabular}{|c|c|c|}
\hline $\begin{array}{c}\text { Interrupted } \\
\text { aortic arch }\end{array}$ & 2 & $\begin{array}{c}\text { Anencephaly with spina bifida, } \\
\text { cleft lip/palate, polydactyly and } \\
\text { syndactyly of ring and little finger }\end{array}$ \\
\hline $\begin{array}{c}\text { Abnormal origin } \\
\text { of right } \\
\text { subclavian artery }\end{array}$ & 1 & Gastroschisis with limb deformity \\
\hline $\begin{array}{c}\text { Tetralogy of } \\
\text { Fallot }\end{array}$ & 1 & No obvious external malformation \\
\hline VSD & 4 & $\begin{array}{c}\text { Hydrocephalous, } \\
\text { craniothoracopagus }\end{array}$ \\
\hline ASD & 1 & Anencephaly with spina bifida \\
\hline Table 2: Cardiac Anomalies Extracardiac Anomalies \\
\hline
\end{tabular}

In Table 2 shows cardiac anomalies associated with extracardiac anomalies; VSD was the commonest of all and it was seen along with other cardiac anomalies.

\section{DISCUSSION}

The normal development is an integrated process of cellular proliferation, differentiation and growth. Any deviation from the normal process leads to various malformations. Congenital malformations of heart accounts for about $1 / 4$ of all developmental defects. ${ }^{5}$ The chance of having malformed child is 5-10 times higher among consanguineous parents. $6,7,8$

Kulkarni in his study found malformations of major body systems to be significantly more common amongst consanguineous couples, whereas malformations of eye, ear and skin did not show any gross effects of consanguinity. ${ }^{8}$

Sheridan and Colleagues et al. presented specific types of defect diagnosed and showed an increased prevalence of cardiac and nervous system anomalies in the progeny of first cousins: microcephaly, atrial septal defects, ventricular septal defects and patent ductus arteriosus were especially frequent. ${ }^{9}$ In one study 740 anomalies were diagnosed in 451 children, no additional information was provided on the occurrence of several anomalies in individual children or on allelic heterogeneity. Both of these issues have been reported in other highly consanguineous populations.10,11,12 and could affect well-being and survival.

In India, uncle-niece marriages were the most common consanguinity type followed by the first cousin type. Uncleniece marriage is not present in Arabs and religiously it is forbidden in Islam and Muslim's populations. ${ }^{13}$ In this study, we found almost 10 times higher congenital anomalies both cardiac and extracardiac, probably because in South India uncle-niece marriage is very common. First cousin marriages also were the most common recorded consanguinity and the risk of developing congenital cardiac anomalies in babies born from first cousin parents when compared with non-related parents was 4 times higher and 3 times higher in babies born from far related parents. This was consistent with results of Yunisin, which first cousin consanguinity risk was 2.3 times higher and far relatives 1.8 times higher when compared with non-related parents. ${ }^{14}$

Children born from consanguineous parents had significantly higher incidence of congenital abnormalities than non-consanguineous families.15,16,17 Several studies have showed the incidence of congenital heart disease (CHD) increased in consanguineous than non-consanguineous families. ${ }^{18,19,20,21}$

The incidence of CHD is ranging between $0.5-0.8 \%$ of live births and it is higher in stillborn, abortions and premature deliveries compared with full-term deliveries and will increase to $2-6 \%$ in a second pregnancy after the birth of a child with CHD or if one of his parents is also affected by one of these congenital anomalies. ${ }^{22}$ In India, CHD is the most common congenital anomalies and represent $30 \%$ of their total anomalies. ${ }^{23} \mathrm{CHD}$ is one of the most common recorded birth defects. ${ }^{18,22,23}$ most of these malformations are multifactorial in origin resulting from the combined genetic, teratogens and environmental factors and in small percentage are due to chromosomal abnormalities. ${ }^{17,18,24}$ Consanguinity increased the incidence of congenital malformations due to the expression of the deleterious recessive genes causing such 
anomalies. ${ }^{25,26}$ The finding what we have in this study is quite comparable to the literature.

\section{CONCLUSION}

Our work shows modest results to the fact that despite few monetary and social benefits in consanguineous marriages the loss is immense as far as congenital cardiac and extracardiac anomalies is concerned, so we should try to create an awareness regarding the negative aspect of consanguineous marriage in the society, so that the congenital anomalies could be minimized. Many might deny but then many articles over the decades have come out against the culture of consanguinity since society has been witnessing the ill effect of it.

\section{BIBLIOGRAPHY}

1. Grey RF. Causes of deafness in schools for the deaf in Madras. Int J Pediatr Otorhinolaryn 1984;18:97-106.

2. Rajangam S, Devi R. Consanguinity and chromosomal abnormality in mental retardation and/or multiple congenital anomaly. J Anat Soc India 2007;56(2):30-33.

3. Sorouri A. Consanguineous marriage and congenital anomalies. First edition, Isfahan University of Medical Sciences, 1380:1-15.

4. Bromiker R, Glam-Baruch M, Gofin R, et al. Association of parental consanguinity with congenital malformations among Arab new-borns in Jerusalem. Clin Genet 2004. Jul; 66(1):63-66 10.1111/j.0009-9163.2004.00264.x.

5. Datta AK. The circulatory system. Essential of human embryology, $3^{\text {rd }}$ edition. Current Books International, Calcutta, Bombay, Madras 1995;166:176-179.

6. Chinara PK, Singh Sameer. East-West differentials in congenital malformations in India. Indian J Paediatr 1982;49:325-329.

7. Kulshrestha $R$, Nath LM, Upadhya P. Congenital malformations in live born infant in a rural community. Indian Paediatr 1983;20:45-49.

8. Kulkarni ML and Kurian M. Consanguinity and its effect on fetal growth and development. A South Indian Study. J Med Genet 1990;27:348-52.

9. Sheridan E, Wright J, Small N, et al. Risk factors for congenital anomaly in a multiethnic birth cohort: an analysis of the Born in Bradford study. Lancet 2013; (Published online July 4) http://dx.doi.org/10.1016/S0140-6736(13)61132-0).

10. Bittles AH and Black ML. Evolution and Health Sackler Colloquium: consanguinity, human evolution and complex diseases. Proc Natl Acad Sci USA. 2010;107:1779-1786.

11. Zlotogora J. Multiple mutations responsible for frequent genetic diseases in isolated populations. Eur J Hum Genet 2007;15:272-278.
12. Romdhane L, Kefi, R, Azaiez, H, et al. Founder mutations in Tunisia: implications for diagnosis in North Africa and Middle East. Orphanet J Rare Dis 2012;7:52.

13. Ramegowda S, Ramachandra NB. Parental consanguinity increase congenital heart disease in South India. Ann Hum Biol 2006;33:519-528.

14. Yunis K, Mumtaz G, Bitar F, et al. Consanguineous marriage and congenital heart defects: a case control study in the neonatal period. Am J Med Genet A 2006;140:1524-1530.

15. Tadmouri GO, Nair P, Obeid T, et al. Consanguinity and reproductive health among Arabs. Reprod Health 2009;6:17.

16. Sawardekar KP. Profile of major congenital malformations at Nizwa Hospital, Oman: 10-year review. J Paediatr Child Health 2005;41:323-330.

17. El Mouzan MI, Al Salloum AA, Al Herbish AS, et al. Consanguinity and major genetic disorders in Saudi children: a community based cross-sectional study. Ann Saudi Med 2008;28:169-173.

18. Nabulsi MM, Tamim H, Sabbagh $M$, et al. Parental consanguinity and congenital heart malformations in a developing country. Am J Med Genet A 2003;116A:342347.

19. Becker SM, Al Halees Z, Molina C, et al. Consanguinity and congenital heart disease in Saudi Arabia. Am J Med Genet 2001;99:8-13.

20. Bassili A, Mokhtar SA, Dabous NI, et al. Risk factors for congenital heart diseases in Alexandria, Egypt. Eur J Epidemiol 2000;16:805-814.

21. Rittler M, Liascovich R, López-Camelo J, et al. Parental consanguinity in specific types of congenital anomalies. Am J Med Genet 2001;102:36-43.

22. Bernstein D. Epidemiology and Genetic Basis of Congenital Heart Disease. In: Behrman RE, Kliegman RM, Jenson HB editors. Nelson Text Book of Paediatrics 2004; 17th ed. Philadelphia Elsevier Sounders; P. 1499-1501.

23. Smitha R, Ramachandra NB. An understanding of the genetics of congenital heart diseases. Ind J Hum Genet 2005;11:15-24.

24. Clark EB. Etiology of congenital cardiovascular malformations: epidemiology and genetics. In: Allen DD, Clark EB, Gutgesell XX, Driscoll DJ, editors. Moss and Adams' heart disease in infants, children and adolescents 2001. Philadelphia: Lippincott Williams and Wilkins: P 7475.

25. Mokhtar MM, Abdel-Fattah MM. Consanguinity and advanced maternal age as risk factors for reproductive losses in Alexandria, Egypt. Eur J Epidemiol 2001;17:559565.

26. Barbour B, Salameh P. Consanguinity in Lebanon: prevalence, distribution and determinants. J Biosoc Sci 2009;41:505-517. 